\title{
Acceptance Process Model of Patients' Life with Terminally Ill in Home Hospice and Development of a Narrative Approach for Nurses
}

\author{
Michiyo Ando' ${ }^{1}$ Hiroko Kukihara2 ${ }^{2}$ Mayumi Yamamoto ${ }^{3}$, Yasuyoshi Ninosaka ${ }^{4}$, Naoyuki Saito ${ }^{5}$ \\ ${ }^{1}$ St. Mary's College, Kurume, Japan \\ ${ }^{2}$ Fukuoka University, Fukuoka, Japan \\ ${ }^{3}$ International University of Health and Welfare, Fukuoka, Japan \\ ${ }^{4}$ Ninosaka Clinic, Fukuoka, Japan \\ ${ }^{5}$ Saito Clinic, Kurume, Japan \\ Email: andou@st-mary.ac.jp
}

How to cite this paper: Ando, M., Kukihara, H., Yamamoto, M., Ninosaka, Y. and Saito, N. (2019) Acceptance Process Model of Patients' Life with Terminally Ill in Home Hospice and Development of a Narrative Approach for Nurses. Journal of Cancer Therapy, 10, 316-326.

https://doi.org/10.4236/jct.2019.104025

Received: March 5, 2019

Accepted: April 5, 2019

Published: April 8, 2019

Copyright $\odot 2019$ by author(s) and Scientific Research Publishing Inc. This work is licensed under the Creative Commons Attribution International License (CC BY 4.0).

http://creativecommons.org/licenses/by/4.0/

\begin{abstract}
The prime aim of this study was to find a psychological process model of patients with terminally ill in home hospice investigating the contents of a narrative, and the secondary aim was to create a narrative approach program for nurses. Ten patients narrated their thinking or feelings along with some prepared questions in two sessions. Patients' narrative data were categorized by a qualitative analysis and 34 categories were chosen. They perceived good points in home hospice like "Being able to spend time freely", "Close relationships with care staffs and strong confidence", though they perceived trouble points like "Suffering from putting burden on the people around me" or "Worries about economic problems". They perceived psychological changes through illness like "Having peace of mind and becoming kind" "Desire for a natural death". Moreover they perceived their life like "Acceptance of one's life including illness" "My life lived with satisfaction". They regarded as important things such as "Spending life time usefully" "Feelings of my family members and of those around me", and as hopes "Hope to leave my living proof" "Living left time to the fullest". From these categories, we propose an acceptance model of patients' life and a narrative program for nurses.
\end{abstract}

\section{Keywords}

Narrative Approach, Terminally Ill Cancer Patients, Home Hospice, Nurses, Acceptance Model 


\section{Introduction}

In these days psychotherapeutic intervention is important in the view of the rising prevalence and mortality rates from cancer and other non-communicable diseases, largely due to the ageing of the world' population [1]. These people feel various kind of suffering like anxiety or depression, and one of the most serious is psycho-existential suffering, which is also called spiritual pain. One of the origins of this pain is the perceived loss of a future [2]. Spiritual pain consists of loss of meaning of life or loss of peace in mind.

For this suffering, there are various mental or psychotherapeutic interventions such as cognitive behavior therapy [3] or meaning-center group psychotherapy [4] for advance cancer patients. Though there are useful, terminally ill cancer patients sometimes may be hard to participate in group or formal counseling session. A life review interview was effective for spiritual pain or psychological distress [5] of terminally ill patients; however some patients did not hope to review their memories and some had severe past memories. To integrate sweet memories and severe memories of patients require professional skills for counseling for nurses. To propose psychological care by nurses, we need to develop another one.

A narrative approach was another useful psychotherapy which includes narrative theory. White and Epson demonstrated a narrative therapy [6]. It comes from social constructivism, and the meaning emerged from narratives between an interviewer and an interviewee. Narrative is an important way of constructing meaning [7], and people create meaning of illness, suffering, and death through narrative, by telling a story [8] [9]. A narrative approach was seemed to be suitable intervention for terminally ill patients to construct meaning.

Regarding narrative research, many are case studies. In this condition, Bronna, et al. [7] discussed the process of meaning construction, and Stanley and Hurst [8] showed a method of building empathy. Qualitative analyses of narratives at the end of life are very few; Tait, et al. [10] conducted Dignity therapy in which patients narrated their lives for legacy. Qualitative analyses were conducted by physicians who found three types: Evaluation narrative, Transition narrative, and Legacy narratives.

The above studies were almost entirely conducted in hospitals or palliative care wards, not at home hospice. And most of the interviewers were conducted by psychologists, physicians, social workers, and so on, not nurses. In the near future, the number of patients who spend time at home at the end of life, and the number of visiting nurses who take care of them in home hospice will increase and psychotherapeutic intervention by nurses will be required. Then we conducted a narrative approach by nurses for terminally ill patients in home hospice, analyzed the contents of the narrative to understand patients' subjective thinking and feeling, and created a program for nurses to conduct in home hospice.

\section{Methods}

Participants: We attempted to recruit 12 patients, two declined to participate, 
and 10 participated. They were patients in three kinds of clinics in Japan (Table 1). The mean age was 68.9 years old. The participants had various primary diseases, and a Performance Status (PS) [11] from 2 to 4 . The stage of cancer was "4" or recurrence. The inclusion criteria were terminally ill patients who used home hospice, were aged $\geq 20$ years old, and had physical strength to talk about 60 minutes. The exclusion criteria were patients with cognitive impairment or serious mental illness.

Procedure: The following is the recruit method. The primary physician introduced the study to a patient who met the inclusion criteria. Patients who showed interest were registered and the researchers sent a letter about the research. After sending a letter, the researcher explained the details of the study to the candidate by telephone. If he or she agreed to participate, they decided the place and time for an interview. The interviewer visited a patient's home or a clinic, and explained about the research again, and received informed consent after agreement for participation.

In the Narrative approach, there were two sessions. We prepared some question referring to previous studies to promote patients' narrative [12] [13].

In the first session, there were the following questions, 1) How did you live before your illness? 2) How did you live after becoming ill? 3) What are difficulties in your life in home hospice, and how do you cope with them? 4) What are good thing in your life in home hospice? In the second session, the following questions were asked, 5) What were the changes after getting your illness? 6) What are the most important things in your life? 7) How do you think of your life? and 8) What is your hope in the future? With participants' permission, their narrative was recorded on IC recorders. Before the first session and after the second session, the participants completed questionnaires. Each session lasted about 60 minutes. They completed some psychological questionnaires; these quantitative results are reported in another occasion. This study was approved by the ethical boards of St. Mary's College.

Table 1. Patient background.

\begin{tabular}{cccccccc}
\hline ID & $\begin{array}{c}\text { Age } \\
\text { (Years })\end{array}$ & Gender & Stage & PS & $\begin{array}{c}\text { Original } \\
\text { disease }\end{array}$ & $\begin{array}{c}\text { Clinical } \\
\text { characteristic }\end{array}$ & Sociodemographic \\
\hline 1 & 60 & M & R & 3 & Lung & Hard to eat & Retirement \\
2 & 70 & M & R & 3 & Laver & Ascites & Retirement \\
3 & 70 & M & R & 4 & Rectal & Tiredness & Company worker \\
4 & 60 & M & IV & 4 & ATL & Hard to breathe & Retirement \\
5 & 50 & M & IV & 2 & Lung & Paralysis of hand & Self employed \\
6 & 40 & F & IV & 2 & Cervix & Edema of leg & Office worker \\
7 & 80 & M & IV & 3 & Stomach & Nothing now & Retirement \\
8 & 90 & F & Terminal & 2 & Heart & Slight cognitive & Retirement \\
9 & 80 & M & R & 2 & Stomach & Physical strength & Retirement \\
10 & 60 & M & IV & 2 & Pancreas & Tiredness & Work officer
\end{tabular}

M: Male, F: Female, R: recurrence. 
Analysis: We conducted qualitative analysis. For narrative data, we employed "qualitative analysis" by Funashima [14] based on the work of Berelson [15] which involves creating codes, subcategories and categories. These narratives were edited into the shortest statement without losing meaning and coded into one subcategory along with similar statements. Similar subcategories were then integrated into one category. To maintain reliability, categorization and coding were validated independently by researchers. Inconsistencies were discussed and negotiated until agreement was reached.

\section{Results}

We recruited 12 patients, two withdrew because of their physical condition, and 10 participated.

We indicate a category as " " and the subcategories as $<>$ in this study. The life before illness was various and the life after illness including medical treatments or daily life was also various. Then we analyzed narratives without these questions. These two questions were useful to begin narrating their lives.

To the question of "What are good things in home hospice?", we chose categories (Table 2) 1) "Being able to spend time freely" like <spending time freely $>$ or $<$ Having fulfilling time and satisfaction $>$, 2) "Open relation to outside world" like $<$ Greeting guests being able to visit freely $>$ or $<$ Getting energy from greeting guests $>$, 3) "Having much time with my family" like $<$ Enabling me to meet family freely $>$ or $<$ Feeling family's warmth $>$, 4) "Close relationships with care staff and strong confidence" like $<$ Getting energy from home visiting $>$ or $<$ Being able to ask questions anytime $>$, and 5) "Reduction in the number of hospital visits" like $<$ Reduction of physical burden $>$ or $<$ Minimum life style change $>, 6)$ "Keeping an independent life in mind" was also chosen.

Table 2. Categories about good points and troubles in home hospice care.

\begin{tabular}{|c|c|c|}
\hline Code & Sub-Categories & Categories \\
\hline $\begin{array}{l}\text { - I can spend time freely at home. } \\
\text { - A day is fulfilling and I am satisfied with it. }\end{array}$ & $\begin{array}{l}\text { - } \quad \text { Spending time freely } \\
\text { - Having fulfilling time and satisfaction }\end{array}$ & 1) Being able to spend time freely \\
\hline $\begin{array}{l}\text { - Students came to see me at any time. } \\
\text { - I could get energy from greeting guests. }\end{array}$ & $\begin{array}{l}\text { - Greeting guests being able to visit freely } \\
\text { - Getting energy from greeting guests }\end{array}$ & 2) Open relation to outside world \\
\hline $\begin{array}{l}\text { - I can spend time together with my family. } \\
\text { - I could feel family's warmth such that my } \\
\text { family celebrated my sixtieth birthday. }\end{array}$ & $\begin{array}{l}\text { - Enabling me to meet family freely } \\
\text { - Feeling family's warmth }\end{array}$ & 3) Having much time with my family \\
\hline $\begin{array}{l}\text { - I could get energy from staff visiting me. } \\
\text { - I can ask questions to home hospice staff anytime. }\end{array}$ & $\begin{array}{l}\text { - Getting energy from home visiting } \\
\text { - Being able to ask questions anytime }\end{array}$ & $\begin{array}{l}\text { 4) Close relationships with care staff } \\
\text { and strong confidence }\end{array}$ \\
\hline $\begin{array}{l}\text { - Since I have edema pain, I appreciate home care. } \\
\text { Home visits are good, because I need not } \\
\text { change my life style. }\end{array}$ & $\begin{array}{l}\text { - Reduction of physical burden } \\
\text { - Minimum life style change }\end{array}$ & $\begin{array}{l}\text { 5) Reduction in the number of } \\
\text { hospital visits }\end{array}$ \\
\hline $\begin{array}{l}\text { - Since I live alone, I do things myself. } \\
\text { - I need to talk with someone and walk. }\end{array}$ & $\begin{array}{l}\text { - I do what I can do myself. } \\
\text { - Maintain self-care consciousness }\end{array}$ & 6) Keeping an independent life in mind \\
\hline
\end{tabular}


To the question of “What are troubles for you during home treatment?", we chose the category (Table 3) 7) "Worries about economic problems" including $<$ Anxiety of longer home treatment $>$ or $<$ Lack of income $>$, 8) "Trouble caused by various physical symptoms" like $<$ Changing body image by ascites $>,<$ Low physical strength $>$, 9) "Suffering from putting a burden on the people around me like <Burden on family members $>$ or <Burden on co-workers $>$, and 10) "Worry about the future of people who remain" like $<$ Single son's future $>$ or $<$ Feeling sorry for taking care for me $>$. Patients consulted physicians about symptoms, a social worker about economic problems.

To the question of "What are changes through illness inexperience?", we chose categories (Table 4), 11) "Positive consciousness for home hospice" like $<$ Being able to communicate with staff $>$ or $<$ Meeting with family freely $>, 12$ ) "Having enough time for self-insight" like $<$ Having enough time to think about things $><$ Being able to wait $>$, 13) "Having peace of mind and becoming kind" like $<$ Leaving for work and having peace of mind $><$ Becoming kinder to others $>$. We chose categories, 14) "Being able to rely on others" like $<$ Being able to express my feeling $><$ Relying on other for what I can't do by myself $>, 15$ ) "Gratitude for encountering reliable physicians" like $<$ Encountering a reliable physician> <Encountering a cheerful physician>, 16) "Desire for a natural death" like <Staying healthy until death $><$ Dying while sleeping $>$, 17) "Consciousness of near death" like $<$ Increasing physical and mental suffering $><$ Increasing sense of tiredness $>$, 18) "Experiencing sense of loss" like $<$ Difficulty of emotion control $><$ Departing from social life $>$.

To the question of "What is important for you", we chose categories (Table $5)$, 19) "Spending left time usefully", like <Living usefully $>$ or $<$ Evaluation of my feeling $>$, 20) "Feelings of my family members and of those around me" like $<$ Understanding feeling of others $>$ or $<$ Feeling of my family members $>, 21$ ) "Family members who take care of me" like <Family as the most important $>$ or $<$ Not giving troubles $>$, 22) "Relationships to generations and encounters with people" like $<$ Parents who raised me $>$ or $<$ Encounter with a child $>$.

Tables 3. Categories about trouble points.

\begin{tabular}{|c|c|c|}
\hline Code & Sub-Categories & Categories \\
\hline $\begin{array}{l}\text { - I am worry about treatment costs. } \\
\text { - We lack income. }\end{array}$ & $\begin{array}{l}\text { - Anxiety of longer home treatment } \\
\text { - Lack of income }\end{array}$ & 7) Worries about economic problems \\
\hline $\begin{array}{l}\text { There are troubles with meals, excretion, side effects, } \\
\text { pain, edema, or feeling tiredness. } \\
\text { - My physical strength seems to decrease after operations. }\end{array}$ & $\begin{array}{l}\text { - } \quad \text { Changing body image due to as cites } \\
\text { - } \quad \text { Low physical strength }\end{array}$ & $\begin{array}{l}\text { 8) Trouble caused by various } \\
\text { physical symptoms }\end{array}$ \\
\hline $\begin{array}{l}\text { - I am suffering from burdening my family. } \\
\text { - I am suffering from burdening my co-workers } \\
\text { in my company. }\end{array}$ & $\begin{array}{l}\text { Burden on family members } \\
\text { or co-workers }\end{array}$ & $\begin{array}{l}\text { 9) Suffering from putting a burden } \\
\text { on the people around me }\end{array}$ \\
\hline $\begin{array}{l}\text { - I am worried about my single sons' future. } \\
\text { - I am sorry for my son for taking care of me. }\end{array}$ & $\begin{array}{l}\text { - } \quad \text { Single son's future } \\
\text { - } \quad \text { Feeling sorry for taking care for me }\end{array}$ & $\begin{array}{l}\text { 10) Worries about the future } \\
\text { of people who remain }\end{array}$ \\
\hline
\end{tabular}


Table 4. Categories about the changes through illness.

\begin{tabular}{|c|c|c|}
\hline Code (samples) & Sub-Categories & Categories \\
\hline $\begin{array}{l}\text { - I can always communicate with staff. } \\
\text { - I can meet with my family freely at home hospice. }\end{array}$ & $\begin{array}{l}\text { - Being able to communicative with staff } \\
\text { - Meeting with family freely }\end{array}$ & $\begin{array}{l}\text { 11) Positive consciousness for } \\
\text { home hospice }\end{array}$ \\
\hline $\begin{array}{l}\text { - I began to think about things slowly. } \\
\text { - I began to be able to wait. }\end{array}$ & $\begin{array}{l}\text { - Having enough to think about things } \\
\text { - Being able to wait }\end{array}$ & 12) Having enough time for self-insight \\
\hline $\begin{array}{l}\text { - I am relaxed since I am released from duty. } \\
\text { - I became kinder because of enough time. }\end{array}$ & $\begin{array}{l}\text { - Leaving for work and having peace } \\
\text { of mind } \\
\text { - Becoming kinder to others }\end{array}$ & $\begin{array}{l}\text { 13) Having peace of mind and } \\
\text { becoming kind }\end{array}$ \\
\hline $\begin{array}{l}\text { - I became able to rely on my parents. } \\
\text { - I can live relying on others naturally. }\end{array}$ & $\begin{array}{l}\text { - Being able to express my feeling } \\
\text { - Relying on others for what I can't } \\
\text { do by myself }\end{array}$ & 14) Being able to rely on others \\
\hline $\begin{array}{l}\text { - I am very happy to encounter a reliable home } \\
\text { hospice physician. } \\
\text { - I am very happy to meet cheerful physician. }\end{array}$ & $\begin{array}{l}\text { - Encountering a reliable physician } \\
\text { - Encountering a cheerful physician }\end{array}$ & $\begin{array}{l}\text { 15) Gratitude for encountering } \\
\text { reliable physicians }\end{array}$ \\
\hline $\begin{array}{l}\text { - I hope to live happily until I die. } \\
\text { - I hope to die while I sleep. }\end{array}$ & $\begin{array}{l}\text { - Staying healthy until death. } \\
\text { - Dying while sleeping }\end{array}$ & 16) Desire for a natural death \\
\hline $\begin{array}{l}\text { - I feel that death is near. } \\
\text { - I can't walk because of tiredness. }\end{array}$ & $\begin{array}{l}\text { - Increasing physical and mental suffering } \\
\text { - Increasing sense of tiredness }\end{array}$ & 17) Consciousness of near death \\
\hline $\begin{array}{l}\text { - Tears fall down when I am awake. } \\
\text { - I am not contacting others because } \\
\text { I will not be able to respond in the future. }\end{array}$ & $\begin{array}{l}\text { - Difficulty of emotion control } \\
\text { - Departing from social life }\end{array}$ & 18) Experiencing sense of loss \\
\hline
\end{tabular}

Table 5. Categories what is important for you.

\begin{tabular}{lll}
\hline \multicolumn{1}{c}{ Code (samples) } & \multicolumn{1}{c}{ Sub-Categories } & \multicolumn{1}{c}{ Categories } \\
\hline - I am thinking about how I can live usefully. & Living usefully & 19) Spending left time usefully \\
- I regard my feelings as important. & Evaluation of my feeling & \\
- I came to understand the feelings of others. & - Understanding feeling of others & 20) Feelings of my family members \\
- I regard the feelings of my family as the most important. & - Feeling of my family members & and of those around me \\
- I regard my family as the most important. & - Family as the most important & 21) Family members who \\
- I try to not give troubles to my family. & - Not giving troubles & take care of me \\
- I regard my generations relationships as important. & Parents who raised me & 22) Relationships to generations \\
- I encountered a child who I have taken care of & - Encounters with a child & and encounters with people \\
\hline
\end{tabular}

To the question of "How do you feel about your life", we chose categories (Table 6), 23) "Acceptance of own life including illness" like <Destiny $>$ or $<$ Having resignation $>$, 24) "Strong ties with my family" like $<$ Confirmation of family ties $>$ or $<$ Thanks-gratitude for my family $>$, 25) "Satisfaction with my life" like $<$ Having lived freely $>$ or $<$ Thanks gratitude for home hospice $>$, 26) "Living life with self-esteem" like $<$ Full life in which I did what I hoped $><$ Integrating good and bad things in my life $>$, 27) "Regret in taking care of my family" like <Looking back of taking care of my family member and regret $>$.

To the question of "What is your hope for the future", we chose categories (Table 7), 28) "Hope to leave my living proof" like $<$ Hope to leave my living proof $><$ Hope to narrate my life to students $>$, 29) "Living left time to the fullest" 
Table 6. Categories about what do you feel about your life?

\begin{tabular}{llll}
\hline \multicolumn{1}{c}{ Code } & \multicolumn{1}{c}{ Sub-Categories } & \multicolumn{1}{c}{ Categories } \\
\hline - Illness is my destiny. & - & Destiny & 23) Acceptance of one's life including illness \\
- It can't be helped that I had cancer. & - & Having resignation & \\
- It is good that I am a child of my mother. & - & Confirmation of family ties & 24) Strong ties with my family \\
- My wife came to sympathy after her work. & - Thanks-gratitude for my family & \\
- I have lived my life freely. & - Having lived freely & 25) Satisfaction with my life \\
- I am full of gratitude. & - Thanks-gratitude for home hospice & \\
- I feel that my life is full. & - Full life in which I did what I hoped & 26) Living life with high self-esteem \\
- My life is good, integrating good and bad. & - Integrating good and bad thing in my life & \\
- I looked backed at my long-term care, & - Looking back of taking care of & 27) Regret in taking care of my family \\
\hline
\end{tabular}

Table 7. Categories about what are hopes for the future.

\begin{tabular}{llll}
\hline \multicolumn{1}{c}{ Code (samples) } & \multicolumn{1}{c}{ Sub-Categories } & Categories \\
\hline - I want to write an essay about my illness. & - Hope to leave my living proof & 28) Hope to leave my living \\
- I want to tell what I learned and it is my meaning to live. & - $\begin{array}{l}\text { Discover meaning to live through } \\
\text { narrating my experience }\end{array}$ & proof \\
- I want to live left time to the fullest & - Hope to live without regret & 29) Living left time \\
- I want to tell my feeling to my parents. & - Hope to say my feeling to my & to the fullest \\
- I want to spend limited time freely. & parents or friends & 30) Living my life enjoyably \\
- I want to find pleasure. & - Hope to do things I like such as trip or tastes & 31) Living daily life gently \\
- I hope to spend daily life gently. & - Spending time like daily life & 32) Palliating physical \\
- I hope to spend daily life not giving trouble to others. & - Not giving trouble to others & symptoms \\
- I want to walk freely. & - Hope to walk freely & 33) Worries about remaining \\
- I hope for no physical pain. & - Hope to palliate physical pain & people after my death \\
- I want my wife to live strongly. & - Worry about family members after my death & 34) Not to burden on others \\
- I hope that my parents live good days even if I die. & & &
\end{tabular}

like $<$ Hope to live without regret $><$ Hope to say my feeling to my parents or friends $>$, 30) "Living my life enjoyably" like $<$ Hope to do things I life $><$ Hope to find pleasure $>$, 31) "Living daily life gently" like $<$ Spending time like daily life $><$ Not giving trouble to others $>$. 32) "Palliating physical symptoms" like $<$ Hope to walk freely $><$ Hope to palliate physical pain $>$, 33) "Worries about remaining people after my death" $<$ Worry about family members after my death $>$, 34) "Not to burden on others" like $<$ I do not want to give troubles to others $><$ I want to do $>$.

\section{Discussion}

\section{1) Acceptance process model of patients' life in home hospice}

From selected categories, we can propose a process model of patient' life (Figure 1). 


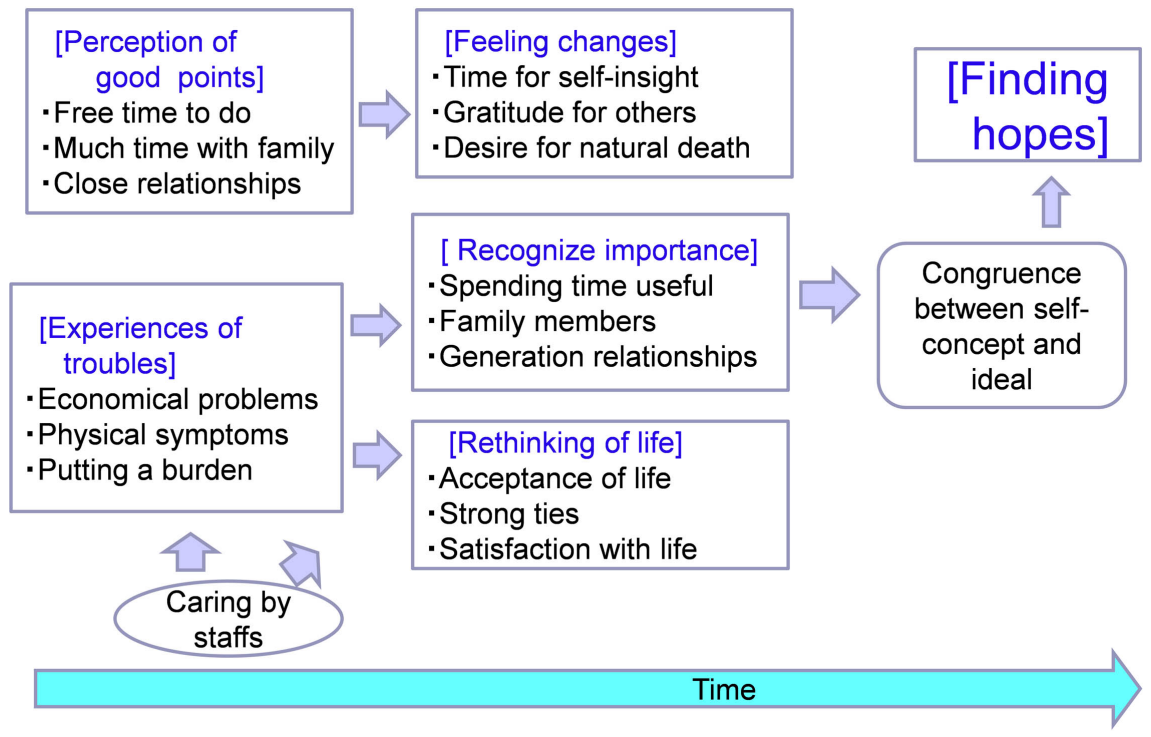

Figure 1. Acceptance process model of patient' life.

Most patients know their disease and prognosis. Patients spend time freely and have much time with family. Greeting people can visit always. Patients have time to insight their minds or thought. They recognize important things for them. They can consult their troubles with medical staffs, although troubles are not always resolved. In receiving medical and mental care by them, they feel familiar relationships and safety. They look back their lives, recognized important things, and feel satisfaction with their lives. Then they can have hopes to future, although not so far future.

In the beginning they can't accept their life, because their self-concept with cancer is not congruent with their ideal. However, they experience the above process like warm human relationships, caring with respect by physicians or nurses, their inconsistency between self-concept and their ideal is reduced. A home hospice proposes these conditions. Redundantly their self-concept and their ideal may congruent. This process is near the person centered approach by Rogers [16]. Congruency promote for patients to accept their lives with illness and have peace of mind. For Japanese, the word of acceptance is near to resignation. We need to obtain the evidence of this model.

\section{2) Required treatments to troubles}

There are some troubles in home hospice. "Worries about economic problems" is related to insurance plan in Japan. Multidisciplinary workers such as social workers can support them and will be needed much more in home hospice. About "Worries about the future of people who remain", medical staffs need to assess the level or kinds of worries and try to resolve realistic problems. A factor of "Troubles caused by various physical symptoms" is the same trouble factor from previous studies [17] [18], although medical staffs proposed care as much as possible. Since physical symptoms affects mental or psychological problem [19] and medical staffs are not stay always in home hospice, explanation about them and coping methods will be needed for patients and families 
much more.

The factor of "Suffering from putting a burden on the people around me" is one of the factors of Good Death [20]. In particular, in home hospice patients feel burden about receiving care from family member. Patients, their families, and medical staffs think and talk about plan of future. A family and a patient need to talk whether they use home hospice or not. In these days, importance of Advance Care Planning (ACP) is pointed [21].

\section{3) Development of the narrative approach program}

In near future, the number of visiting nurses will increase in home hospice. And they are required mental or psychological care. A narrative approach may be useful to nurses. We propose the Narrative Approach program (Table 8) at home hospice by nurses. About questions, it is easy to talk about good points and troubles in home hospice. Then they can found changes after experience illness comparing before illness and recognize important things. They rethink their lives including their illness experience and found new hopes in near future. We set the questions.

Comparing method of life review with this narrative approach, in the life review [22], factors like "Good human relationships and transcendence" "achievement and satisfaction" or "Good memories" are primary concerns and related to high spiritual wellbeing. Also, "Human relationships" or "Pleasant memories" were primary concerns [23]. In these life review method, the question of asking past memories and good memories affected the utility of life review. However, some patients do not want to remember memories. Life review is suitable for people with good memories and with integration power of good and bad memories, however, it needs professional skills like a psychologist and it is hard for a visiting nurse to conduct life review. Comparing a life review, narrative approach is not limited by memories and patients narrated freely. Visiting nurses may conduct this approach and effective.

From recent previous studies, usefulness of narrative is shown. Efficacy of narrative intervention was demonstrated in some previous studies. Lloyd-Williams et al. [12] showed the efficacy on depression; however definite question items were not showed. Wise et al. [13] showed the efficacy of Telephone-based narrative interventions on wellbeing; however since this method need telephone

Table 8. Narrative approach program for patients at home hospice by nurses.

\begin{tabular}{ll}
\hline \multicolumn{1}{c}{ Purpose } & \multicolumn{1}{c}{ Questions } \\
\hline 1) Greetings Ice breaking & How did you live before and after becoming ill? \\
$\begin{array}{ll}\text { 2) Perception of home hospice } & \text { What are good things in your life in home hospice? } \\
\text { 3) Feeling changes } & \text { What are difficulties in your life in home hospice? } \\
\text { 4) Recognizing importance } & \text { What are the most important things in your life? } \\
\text { 5) Rethinking of life } & \text { How do you think of your life? } \\
\text { 6) Finding hopes } & \text { What is your hope in the future? }\end{array}$
\end{tabular}


or social networking system, it may be difficult for some patients. In that situation, the Narrative approach in this study would be convenient.

\section{Funding}

This work was supported in part by JSPS KAKENHI Grant Number JP 17K12559.

\section{Conflicts of Interest}

The authors declare that there is no conflict of interest.

\section{References}

[1] Rodin, G.M. (2017) Psychotherapeutic Interventions near the End of Life: Theory, Evidence, and Future Directions. Australian Psychologist, 52, 335-339. https://doi.org/10.1111/ap.12307

[2] Murata, H. and Morita, T. (2006) Conceptualization of Psycho-Existential Suffering by the Japanese Task Force: The First Step of a Nationwide Project. Palliative and Supportive Care, 4, 279-285. https://doi.org/10.1017/S1478951506060354

[3] Moory, S., Cort, E., Kapari, M., et al. (2009) A Cluster Randomized Controlled Trial of Cognitive Behavioral Therapy for Common Mental Disorders in Patients with Advanced Cancer. Psyhologucal Medicine, 39, 713-723. https://doi.org/10.1017/S0033291708004169

[4] Breitbart, W., Rosenfeld, B., Pessin, H., et al. (2015) Meaning-Centered Group Psychotherapy: AN Effective Intervention for Reducing Despair in Patients with Advanced Cancer. Journal of Clinical Oncology, 33, 749-754. https://doi.org/10.1200/JCO.2014.57.2198

[5] Ando, M., Morita, T., Akechi, T., Okamoto, T., et al. (2010) Japanese Task Force for Spiritual Care. Efficacy of Short-Term Life-Review Interviews on the Spiritual Well-Being of Terminally Ill Cancer Patients. Journal of Pain and Symptom Management, 39, 993-1002.

[6] White, M. and Epson, D. (1990) Narrative Means to Therapeutic Ends. Norton, New York.

[7] Bronna, D. and Romanoff, B.E. (2006) Meaning Construction in Palliative Care: The Use of Narrative, Ritual, and the Expressive Arts. American Journal of Hospice and Palliative Medicine, 23, 309-301.

[8] Stanley, P. and Hurst, M. (2011) Narrative Palliative Care: A Method for Building Empathy. Journal of Social Work in End of Life and Palliative Care, 7, 39-55. https://doi.org/10.1080/15524256.2011.548046

[9] Thomas, C., Reeve, J., Bingley, A., et al. (2009) Narrative Research Methods in Palliative Care Context: Two Case Studies. Journal of Pain and Symptoms Management, 37, 788-796.

[10] Tait, G.R., Schryer, C., McDougall, A., et al. (2011) Lingard L. Exploring the Therapeutic Power of Narrative at the End of Life: A Qualitative Analysis of Narratives Emerging in Dignity Therapy. BMJ Supportive Palliative Care, 1, 296-300.

[11] Oken, M.M., Creech, R.H, Tormey, D.C., et al. (1982) Toxicity and Response Criteria of the Eastern Cooperative Oncology Group. American Journal of Clinical Oncology, 5, 649-656. https://doi.org/10.1097/00000421-198212000-00014

[12] Lloyd-Williams, M., Shiels, C., Ellis, J., et al. (2018) Pilot Randomized Controlled Trial or Focused Narrative Intervention for Moderate to Severe Depression in Pal- 
liative Care Patients: DISCERN Trial. Palliative Medicine, 32, 206-215. https://doi.org/10.1177/0269216317711322

[13] Wise, M., Marchnad, L.R., Roberts, L.J., et al. (2018) Suffering in Advanced Cancer: A Randomized Control Trial of a Narrative Intervention. Journal of Palliative Medicine, 21, 200-207. https://doi.org/10.1089/jpm.2017.0007

[14] Funashima, N. (2001) Challenges in Qualitative Analysis. Igakusyoin, Tokyo. (In Japanese)

[15] Berelson, B. (1952) Content Analysis.

[16] Rogers, C.R. (1995) A Way to Being. Houghton Mifflin, Boston.

[17] Ando, M., Ninosaka, Y., Okamura, K., et al. (2015) Difficulties in Caring for Cancer Patients at the Endo of Life at Home and Complicated Grief. American Jounal of Hospice and Palliative Medicine, 32, 173-177.

[18] Ishi, Y., Miyashita, M., Sato, K., et al. (2012) Family's Difficulty Scale in End-of Life Home Care: A New Measure for the Family's Difficulties in Caring for Patients with Cancer at the End of Life at Home from Bereaved Family's Perspective. Journal of Palliative Medicine, 15, 210-215. https://doi.org/10.1089/jpm.2011.0248

[19] Ohrnbergci, J., Fichera, E. and Sutton, M. (2017) The Relationship between Physical and Mental Health: A Mediation Analysis. Social Science and Medicine, 195, 42-49. https://doi.org/10.1016/j.socscimed.2017.11.008

[20] Miyashita, M., Sanjyo, M., Morita, T., et al. (2007) Good Death in Cancer Care: A Nationwide Qualitative Study. Annals of Oncology, 18, 1090-1097. https://doi.org/10.1093/annonc/mdm068

[21] Izumi, S. (2017) Advance Care Planning: The Nurse's Role. American Journal of Nursing, 117, 56-61. https://doi.org/10.1097/01.NAJ.0000520255.65083.35

[22] Ando, M., Morita, T., Ahn, S., et al. (2009) International Comparison Study on the Primary Concerns of Terminally Ill Cancer Patients in Short-Term Life Review Interviews among Japanese, Koreans, and Americans. Palliative and Supportive Care, 7, 349-355. https://doi.org/10.1017/S1478951509990289

[23] Ando, M., Morita, T., Akechi, T., et al. (2012) Factors in Narratives to Questions in the Short-Term Life Review Interviews of Terminally Ill Cancer Patients and Utility of the Questions. Palliative and Supportive Care, 10, 83-90.

https://doi.org/10.1017/S1478951511000708 